\title{
PENAMBAHAN LISIN PADA PAKAN KOMERSIAL TERHADAP RETENSI PROTEIN DAN RETENSI ENERGI UDANG GALAH (Macrobrachium Rosenbergii)
}

\section{ADDITION OF LYSINE IN COMMERCIAL FEED ON PROTEIN RETENTION AND ENERGY RETENTION GIANT FRESHWATER PRAWN (Macrobrachium rosenbergii)}

\author{
Akbar Falah Tantri ${ }^{1^{*}}$, Boedi Setya Rahardja ${ }^{2}$ dan Agustono ${ }^{2}$. \\ ${ }^{1}$ Program Studi Budidaya Perairan, Fakultas Perikanan dan Kelautan, Universitas Airlangga, Surabaya \\ ${ }^{2}$ Departemen Manajemen Kesehatan Ikan dan Budidaya Perairan, Fakultas Perikanan dan Kelautan, Universitas \\ Airlangga, Surabaya \\ *akbar.falah.tantri-2014@pasca.unair.ac.id
}

\begin{abstract}
Abstrak
Udang galah (Macrobrachium rosenbergii) yaitu salah satu komoditas perikanan air tawar yang memiliki nilai ekonomis. Permasalahan yang saat ini dihadapi dalam budidaya udang galah adalah jangka waktu budidaya yang relatif lebih lama dibandingkan dengan budidaya udang konsumsi lainnya. Upaya yang dapat dilakukan adalah dengan meningkatkan kualitas pakan, salah satunya melalui pemberian feed additive berupa lisin kedalam pakan udang galah.

Penelitian ini bertujuan untuk mengetahui pengaruh penambahan lisin pada pakan komersial terhadap retensi protein dan retensi energi udang galah (Macrobrachium rosenbergii). Penelitian yang dilakukan menggunakan metode eksperimental dengan Rancangan Acak Lengkap (RAL). Analisa data untuk menguji beda nyata menggunakan Analysis of Variant berfungsi untuk mengetahui pengaruh perlakuan.

Hasil penelitian menyebutkan bahwa penambahan lisin pada pakan komersial tidak berbeda nyata ( $p>0,05)$ terhadap retensi protein dan retensi energi udang galah (Macrobrachium rosenbergii). Kualitas air media pemeliharaan udang galah adalah suhu $29-30{ }^{\circ} \mathrm{C}$, Oksigen terlarut 6,9-7,3 mg/l, pH 7-8, Amonia 0-0,25 $\mathrm{mg} / \mathrm{l}$.
\end{abstract}

Kata kunci : Udang galah, Lisin, Retensi Protein, Retensi Energi

\section{Abstract}

Giant Freshwater Prawns (Macrobrachium rosenbergii) is a freshwater fishery commodities economically valuable. The problems currently faced in prawn farming is the cultivation period is relatively long compared with other consumption of shrimp farming. Efforts to do is to improve the quality of feed, such as through the provision of a feed additive lysine feed into the prawns.

This study aim's to determine the effect of lysine in commercial feed on protein retention and energy retention of giant freshwater prawn (Macrobrachium rosenbergii). This research used experimental method with a completely randomized design. Statistical analysis using Analysis of Variant (ANOVA) to determine the effect of treatment.

The results showed that the addition of lysine to the commercial feed was not significant $(\mathrm{p}>0.05)$ on protein retention and energy retention of giant freshwater prawn (Macrobrachium rosenbergii). The water quality used for giant freshwater prawn is $29-30^{\circ} \mathrm{C}$ for temperature, dissolved oxygen from 6.9 to $7.3 \mathrm{mg} / 1$, $\mathrm{pH}$ 7-8, Ammonia 0-0.25 mg / 1.

Key Words : Giant Freshwater Prawn, Lysine, Sargassum sp., Protein Retention, Energy Retention

\section{PENDAHULUAN}

Udang galah merupakan salah satu komoditas perikanan air tawar yang bernilai ekonomis tinggi. Harga udang galah konsumsi berkisar Rp.50.000,00 sampai Rp.70.000,00 per kilogram. Sedangkan jumlah permintaan komoditas udang galah nasional mencapai 10-20 ton/hari (Kementerian Kelautan dan Perikanan, 2012). Produksi udang Indonesia pada 2011 mencapai 400.385 ton, kemudian meningkat menjadi 457.600 ton pada 2012. Adapun untuk 2013 target produksi udang ditetapkan sebesar 660.000 ton. Pengembangan 
budidaya udang galah perlu dilakukan sebagai upaya dalam pemenuhan target produksi yang semakin meningkat (Kementerian Kelautan dan Perikanan, 2013).

Produksi udang galah dapat ditingkatkan dengan mengeliminasi faktor-faktor yang dapat menghambat dan menyelesaikan permasalahan yang ada dalam budidaya udang galah. Beberapa masalah yang dihadapi budidaya udang galah meliputi: kualitas air, penyakit, dan pakan. Tercukupinya kebutuhan nutrisi udang galah melalui asupan pakan menjadi prioritas utama untuk menunjang pertumbuhan. Secara umum, biaya pakan menghabiskan $60-70 \%$ dari biaya produksi (Sibbald, 1982 dalam Agustono dkk., 2011), dimana budidaya udang galah yang dilakukan secara intensif umumnya menggunakan pakan komersial.

Upaya yang dapat dilakukan untuk mengoptimalkan pemanfaatan nutrisi pakan oleh udang galah adalah dengan meningkatkan kualitas pakannya, sehingga pada akhirnya laju pertumbuhan udang galah meningkat serta dibarengi jangka waktu budidaya udang galah yang lebih cepat. Hal ini terkait dengan jangka waktu budidaya udang galah untuk mencapai ukuran konsumsi yang saat ini relatif lebih lama dibandingkan budidaya udang konsumsi lainnya. Metode yang dapat digunakan untuk meningkatkan kualitas pakan adalah dengan pemberian feed additive pada pakan udang galah. Feed additive adalah suatu bahan yang ditambahkan ke dalam pakan dengan jumlah relatif sedikit dengan tujuan tertentu (Agustono dkk., 2011). Salah satu feed additive yang dapat diberikan pada pakan untuk udang adalah asam amino esensial berupa lisin (Gatlin, D. M. and Peng Li. 2008).

Penambahan lisin pada pakan untuk udang windu dan udang vannamei telah dilakukan dan mampu berpengaruh terhadap pemanfaatan nutrisi pakan oleh udang windu dan udang vannamei. Hasil penelitian Biswas et al., (2006) menunjukkan penambahan $1 \%$ lisin dari jumlah pakan dapat meningkatkan efisiensi pemanfaatan protein oleh udang windu
(Penaeus monodon). Penelitian Fengjun et al., (2012) juga mengindikasikan bahwa penambahan $1,515 \%$ lisin dari jumlah pakan berpengaruh terhadap retensi protein Litopenaeus vannamei.

\section{METODOLOGI \\ Waktu dan Tempat}

Penelitian ini dilaksanakan pada bulan April 2014 sampai Juni 2014 di Fakultas Perikanan dan Kelautan, Universitas Airlangga. Analisa proksimat pakan udang dilakukan di Laboratorium Kimia, Universitas Muhammadiyah Malang. Analisa retensi awal dan retensi protein akhir dilakukan di Unit Layanan Pemeriksaan Laboratoris Konsultasi dan Pelatihan, Fakultas Kedokteran Hewan, Universitas Airlangga. Analisa retensi energi akhir dilakukan di Laboratorium Energi-LPPM ITS.

\section{Materi Penelitian}

Peralatan Penelitian

Peralatan yang digunakan dalam penelitian ini adalah akuarium berukuran $15 \times 15 \times 25 \mathrm{~cm}^{3}$ sebanyak 20 buah, aerator, selang aerasi, batu aerasi, seser, baskom, kain lap, kantong plastik hitam, terpal, bak plastik, gelas ukur, timbangan analitik, DO meter, ammonia test kit, $\mathrm{pH}$ paper dan termometer.

\section{Bahan Penelitian}

Bahan-bahan yang digunakan pada penelitian ini adalah tokolan udang galah, air tawar, pakan komersial, lisin dan tepung tapioka.

\section{Metode Penelitian}

Metode penelitian yang digunakan dalam penelitian ini adalah metode eksperimental yang terdiri dari lima perlakuan dengan empat ulangan. Kusriningrum (2008) menyatakan, eksperimen dapat didefinisikan sebagai suatu tindakan yang dibatasi dengan nyata dan dapat dianalisa hasilnya. Rancangan percobaan yang digunakan adalah Rancangan Acak Lengkap (RAL). Kusriningrum (2008) menyatakan 
bahwa rancangan acak lengkap dipergunakan apabila media, alat dan bahan percobaan seragam atau dapat dianggap seragam. Perlakuan yang digunakan dalam penelitian ini adalah sebagai berikut : $\mathrm{P}_{0}$ : pakan tanpa penambahan lisin; $\mathrm{P}_{1}$ : pakan dengan penambahan lisin sebanyak $0,5 \%$; $\mathrm{P}_{2}$ : pakan dengan penambahan lisin sebanyak $1 \% ; \mathrm{P}_{3}$ : pakan dengan penambahan lisin sebanyak $1,5 \% ; \mathrm{P}_{4}$ : pakan dengan penambahan lisin sebanyak $2 \%$.

\section{Prosedur Kerja \\ Persiapan Alat dan Bahan}

Persiapan penelitian dengan membersihkan peralatan yang akan digunakan. Peralatan berupa akuarium, bak plastik, baskom, seser dan terpal dicuci menggunakan sabun dan dibilas kemudian dikeringkan. Aklimatisasi tokolan udang galah dilakukan selama 3 hari. Kemudian dipuasakan selama 1 hari untuk menghilangkan pengaruh pakan sebelumnya. Media pemeliharaan yang akan digunakan adalah air tawar. Air tawar tersebut diisikan sebanyak 1,5 L ke tiap akuarium. Padat tebar udang galah 1 ekor/0,15 L. Masing-masing akuarium berisi 10 ekor udang galah.

\section{Penyediaan Pakan Udang Galah}

Pakan berasal dari pakan komersial dengan penambahan lisin dan binder. Komposisi bahan pakan disesuaikan dengan dosis lisin tiap perlakuan. Komposisi bahan penyusun pakan dapat dilihat pada Tabel 1.

Tabel 1. Bahan penyusun pakan

\begin{tabular}{|l|c|c|c|c|c|}
\hline Komposisi & \multicolumn{5}{|c|}{ Perlakuan } \\
\cline { 2 - 6 } $\begin{array}{c}(100 \text { g-1 } \\
\text { Berat } \\
\text { Kering }\end{array}$ & $\mathrm{P}_{0}$ & $\mathrm{P}_{1}$ & $\mathrm{P}_{2}$ & $\mathrm{P}_{3}$ & $\mathrm{P}_{4}$ \\
\hline $\begin{array}{l}\text { Pakan } \\
\text { Komersial }\end{array}$ & 79 & 78,5 & 78 & 77,5 & 77 \\
\hline $\begin{array}{l}\text { Tepung } \\
\text { Tapioka }\end{array}$ & 21 & 21 & 21 & 21 & 21 \\
\hline Lisin & - & 0,5 & 1 & 1,5 & 2 \\
\hline
\end{tabular}

Tepung tapioka pada pakan digunakan sebagai binder. Hal ini bertujuan keti- ka pakan udang diberikan, lisin yang terkandung didalamnya tidak larut dalam air dan dapat dimanfaatkan oleh udang untuk sintesa protein tubuh (Shah Alam et al., 2005). Sebelum digunakan sebagai binder, tepung tapioka dimasak dengan air sambil diaduk hingga menjadi adonan yang mengental.

Lisin ditimbang sesuai dosis tiap perlakuan kemudian dicampur dengan $6 \mathrm{~g}$ adonan tepung tapioka. Campuran tersebut kemudian dicampur dengan pakan komersial, serta ditambahkan dengan $15 \mathrm{~g}$ adonan tepung tapioka. Penggunaan jumlah binder yang cukup banyak dikarenakan agar lisin dapat terlapisi sempurna dan tercampur merata pada pakan komersial. Setelah semua bahan tercampur, kemudian pakan dikeringkan pada oven dengan suhu $40{ }^{\circ} \mathrm{C}$. Setelah pakan tersebut kering, diremahkan sampai menjadi bentuk flake (Richard et al, 2009). Pakan pada tiap perlakuan yang telah jadi dilakukan analisa proksimat untuk mengetahui kandungan nutrisinya.

\section{Manajemen Kualitas Air}

Pada proses pemeliharaan udang galah dilakukan manajemen kualitas air dengan cara menyifon kotoran dan sisa pakan setiap hari pada pukul 15.00 WIB, serta dilakukan pergantian air sebanyak $50 \%$ saat penyifonan.

\section{Pelaksanaan Penelitian}

Penelitian ini dilakukan selama 35 hari. Pemberian pakan dilakukan sebanyak 3 kali/hari pada pukul 08.00, 16.00 dan 21.00 WIB. Jumlah pakan yang diberikan sebanyak 10\% dari biomass udang galah (Nguyen Thi Ngoc Anh et al, 2009). Jumlah pakan yang diberikan ditentukan setiap tujuh hari, dilakukan perhitungan biomass dengan cara penimbangan bobot seluruh populasi udang galah.

\section{Parameter Penelitian}

Parameter utama yang diamati adalah retensi protein dan retensi energi udang

Diterima/submitted: 11 Februari 2016

Disetujui/accepted: 25 Juni 2016 
galah. Parameter penunjang penelitian ini adalah suhu, $\mathrm{pH}, \mathrm{DO}$ dan ammonia.

\section{HASIL DAN PEMBAHASAN \\ Retensi Protein dan Retensi Energi}

Dari hasil penelitian didapatkan nilai retensi protein yang berkisar 45,3995 - 54,90425 \%, serta nilai retensi energi yang berkisar 3,35425 - 4,959\%. Dari hasil analisa statistik menunjukkan bahwa penambahan lisin pada pakan komersial menunjukkan hasil yang tidak berbeda nyata $(p>0,05)$ terhadap retensi protein dan retensi energi udang galah.

\section{Kualitas Air}

Data kisaran kualitas air selama penelitian dapat dilihat pada Tabel 2.

Tabel 2. Nilai Kisaran Parameter Kualitas Air Pemeliharaan Udang Galah

\begin{tabular}{|l|l|l|l|}
\hline No & Parameter & Satuan & Kisaran \\
\hline 1 & Suhu & ${ }^{\circ} \mathrm{C}$ & $29-30$ \\
2 & Oksigen terlarut (DO) & $\mathrm{mg} / 1$ & $6,9-7,3$ \\
3 & $\mathrm{pH}$ & - & $7-8$ \\
4 & Ammonia & $\mathrm{mg} / \mathrm{l}$ & $0-0,25$ \\
\hline
\end{tabular}

\section{Pembahasan \\ Retensi Protein}

Berdasarkan analisa statistik menunjukkan bahwa penambahan lisin pada pakan komersial menunjukkan hasil yang tidak berbeda nyata $(p>0,05)$ terhadap retensi protein udang galah. Hal tersebut menunjukkan bahwa pemberian lisin sebagai feed additive pada pakan untuk udang galah tidak dapat meningkatkan nilai retensi protein yang lebih baik dibandingkan pakan tanpa penambahan lisin sebagai kontrol. Hal ini diduga karena protein yang telah diserap, terlebih dahulu dimanfaatkan oleh tubuh udang untuk aktivitas, metabolisme dan kebutuhan pemeliharaan. Kemudian jika berlebih akan disimpan atau diretensi dalam tubuh untuk membangun jaringan protein tubuh (dimanfaatkan bagi pertumbuhan).

Pertumbuhan diasumsikan sebagai pertambahan jaringan struktural, yang berarti pertambahan (peningkatan) jumlah protein dalam jaringan tubuh. Cepat tidaknya pertumbuhan udang, ditentukan oleh banyaknya protein yang dapat diserap dan dimanfaatkan oleh tubuh udang sebagai zat pembangun. Hampir semua jaringan secara aktif mengikat asam-asam amino dan menyimpannya secara intraseluler dalam konsentrasi yang lebih besar, untuk dibentuk menjadi protein tubuh (sel-sel tubuh) (Buwono, 2000).

\section{Retensi Energi}

Berdasarkan analisa statistik menunjukkan bahwa penambahan lisin pada pakan komersial menunjukkan hasil yang tidak berbeda nyata $(p>0,05)$ terhadap retensi energi udang galah. Hal ini diduga karena sebelum disimpan atau diretensi dalam tubuh, energi yang diserap telah banyak dimanfaatkan oleh tubuh udang untuk aktivitas, metabolisme dan kebutuhan pemeliharaan. Handajani dan Widodo (2010) menyatakan bahwa tidak semua energi yang yang masuk dapat dicerna dan dimanfaatkan untuk pertumbuhan. Energi yang masuk akan digunakan terlebih dahulu untuk aktivitas, metabolisme, dan kebutuhan pemeliharaan. Kemudian sisanya digunakan untuk pertumbuhan dan reproduksi.

Hal ini apabila dibandingkan dengan nilai retensi proteinnya maka dapat dilihat hasilnya sama, yaitu pada analisa statistik retensi protein menunjukkan hasil yang juga tidak berbeda nyata $(p>0,05)$. Dengan hasil yang demikian maka dapat diduga bahwa terjadi keseimbangan antara jumlah kandungan energi dan protein pada pakan tiap perlakuan, sehingga kandungan energi dan protein yang mampu diretensi 
dalam tubuh udang galah menunjukkan hasil yang tidak berbeda nyata $(\mathrm{p}>0,05)$.

Tacon (1987) menyatakan bahwa pemenuhan sumber energi (kadar energi dan protein) dalam pakan harus seimbang, karena kelebihan atau kekurangan energi dapat menyebabkan penurunan laju pertumbuhan. Pemberian pakan dengan kandungan energi yang rendah menyebabkan penggunaan sebagian protein untuk pemenuhan kebutuhan energi, sehingga jumlah protein yang dapat dimanfaatkan bagi pertumbuhan udang akan berkurang.

Hal ini juga didukung oleh pendapat Buwono (2000) yang menyatakan bahwa keseimbangan antara kadar energi dan protein sangat berperan penting dalam pertumbuhan, karena apabila kebutuhan energi kurang maka protein akan dipecah dan digunakan sebagai sumber energi. Pemanfaatan sebagian protein sebagai sumber energi ini akan menyebabkan pertumbuhan udang terhambat.

\section{Kualitas Air}

Kualitas air dalam budidaya udang memegang peranan yang sangat penting. Kualitas air dapat didefinisikan sebagai kesesuaian air bagi kelangsungan dan pertumbuhan udang, yang umumnya ditentukan oleh beberapa parameter kualitas air (Mahasri dkk., 2009). Beberapa parameter utama kualitas air yang diukur dalam penelitian ini yaitu, suhu, oksigen terlarut (DO), $\mathrm{pH}$, dan amonia.

Nilai kisaran suhu selama penelitian berkisar antara $29-30^{\circ} \mathrm{C}$. Hal ini sesuai dengan pendapat Tidwell et al., (2002) yang memberikan batasan nilai toleransi udang galah terhadap suhu pada kisaran $25{ }^{\circ} \mathrm{C}$ sampai $32{ }^{\circ} \mathrm{C}$. Kondisi perairan dengan suhu dibawah $25{ }^{\circ} \mathrm{C}$ menyebabkan proses kematangan seksual udang galah terganggu, sehingga menyebabkan sebagian energi yang seharusnya digunakan untuk pertumbuhan dialihkan untuk proses kematangan seksual. Udang galah masih dapat hidup dalam waktu singkat pada suhu $19{ }^{\circ} \mathrm{C}$ atau diatas $34{ }^{\circ} \mathrm{C}$, sedangkan pada suhu $13{ }^{\circ} \mathrm{C}$ dapat me- nyebabkan kematian pada udang (Tidwell et al., 2002).

Hasil pengukuran Dissolved Oxygen (DO) atau oksigen terlarut selama penelitian berkisar antara 6,9-7,3 $\mathrm{mg} / \mathrm{l}$. D'Abramo et al., (2006) menyatakan bahwa kandungan oksigen terlarut sebesar $3 \mathrm{mg} / \mathrm{l}$ atau lebih dalam perairan sudah mendukung kehidupan udang galah secara normal. D'Abramo et al., (2009) menyatakan bahwa kandungan oksigen terlarut yang optimal untuk pemeliharaan udang galah tidak boleh kurang dari $5 \mathrm{mg} / \mathrm{l}$.

Hasil pengukuran nilai $\mathrm{pH}$ selama penelitian berkisar antara 7-8. Hal ini sesuai dengan pendapat D'Abramo et al., (2006) yang menyatakan nilai pH optimal dalam pemeliharaan udang galah berkisar antara 7 - 8,5. Pada lingkungan perairan dengan $\mathrm{pH}$ kurang dari 6,5 atau lebih dari 9,5 udang galah dewasa masih dapat hidup dengan pertumbuhan yang sangat lambat, namun $\mathrm{pH}$ lebih dari 9 dapat menyebakan kematian pada juvenile udang galah.

Dalam budidaya sisa pakan dalam bentuk feses atau yang tidak termakan berperan besar dalam penurunan kualitas air, ditandai dengan kandungan amonia yang tinggi. Konsentrasi ammonia selama penelitian berkisar antara 0-0,25 $\mathrm{mg} / \mathrm{l}$. Secara ideal konsentrasi ammonia yang terkandung dalam air tidak boleh lebih dari $1 \mathrm{mg} / \mathrm{l}$. Kadar ammonia yang terlalu tinggi dapat menghambat pertumbuhan dan dalam jangka panjang dapat menyebabkan kematian (Tidwell et al., 2002).

\section{KESIMPULAN DAN SARAN Kesimpulan}

Berdasarkan hasil penelitian, maka dapat ditarik kesimpulan bahwa penambahan lisin pada pakan komersial tidak berpengaruh terhadap retensi protein dan retensi energi udang galah (Macrobrachium rosenbergii).

\section{Saran}

Berdasarkan hasil penelitian yang telah dilakukan, perlu dilakukan penelitian lebih lanjut mengenai efektivitas pengaruh 
jenis feed additive lainnya terhadap udang galah (Macrobrachium rosenbergii).

\section{DAFTAR PUSTAKA}

Agustono., H. Setyono., T. Nurhajati., M. Lamid., M. A. Al-Arief., W. P. Lokapirnasari. 2011. Praktikum Teknologi Pakan Ikan. Fakultas Perikanan dan Kelautan. Universitas Airlangga. Surabaya. hal. 3, 7.

Biswas, P., A. K. Pal., N. P. Sahu., A. K. Reddy., A. K. Prusty and S. Misra. 2007. Lysine and/or phytase supplementation in the diet of Penaeus monodon (Fabricius) juveniles: Effect on growth, body composition and lipid profile. Aquaculture 265 (253-260). 7 p.

Buwono, I. D. 2000. Kebutuhan Asam Amino Esensial dalam Ransum Ikan. Kanisius. Jogyakarta. hal. 11, 12, 13, 17, 18, 30.

D’Abramo, L. R., J. H. Tidwell., M. Fondren and C. L. Ohs. 2006. Pond Production of the Freshwater Prawn in Temperate Climates. United States Department of Agriculture. Southern Regional Aquaculture Centre. 8 p.

D’Abramo, L. R., J. L. Silva and M. O. Frinsko. 2009. Sustainable Farming of Freshwater Prawns and the Assurance of Product Quality. Division of Agriculture, Forestry, and Veterinary Medicine. Mississippi State University. $16 \mathrm{p}$.

Fengjun, Xie., Wenping, Zeng., Qicun, Zhou., Hualang, Wang., Tuo, Wang., Changqu, Zheng and Yongli, Wang. 2012. Dietary Lysine Requirement Of Juvenile Pacific White Shrimp (Litopenaeus Vannamei). Aquaculture 358-359. (116-121). 6 p.

Handajani dan W. Widodo. 2010. Nutrisi Ikan. UMM Press. Universitas Muhammadiyah Malang. Malang. hal. 62-75, 98.

Kementerian Kelautan dan Perikanan. 2012. Indonesian Fisheries Statistic Index.

http://www.kkp.go.id/index.php/arsip /c/7667/optimalkan-lahan-sawah- kkp-galakkan-udang-galah-danpadi/. 29 Januari 2014. 1 hal.

Kementerian Kelautan dan Perikanan. 2013. Indonesian Fisheries Statistic Index.

http://www.kkp.go.id/index.php/arsip /c/9199/Produksi-Udang-BisaCapai-660.000-Ton-pada-2013/. 29 Januari 2014. 1 hal.

Kusriningrum, R. S. 2008. Perancangan Percobaan. Universitas Airlangga. Surabaya. hal. 43-63.

Mahasri, G., A. S. Mubarak dan M. A. Alamsjah. 2009. Bahan Ajar: Manajemen Kualitas Air. Fakultas Perikanan dan Kelautan. Universitas Airlangga. hal. 7.

Nguyen Thi Ngoc Anh, Tran Thi Thanh Hien, W. Mathieu, Nguyen Van Hoa and P. Sorgeloos. 2009. Effect of Fishmeal Replacement with Artemia Biomass as a Protein Source in Practical Diets for The Giant Freshwater Prawn (Macrobrachium rosenbergii). Aquaculture Research 40 (669680). $11 \mathrm{p}$.

Richard, L., P. P. Blanc., V. Rigolet., S. J. Kaushik and I. Geurden. 2009. Maintenance and growth Requirements for Nitrogen, Lysine and Methionine and Their Utilisation Efficiencies in Juvenile Black Tiger Shrimp (Penaeus monodon) Using a Factorial Approach. British Journal of Nutrition (2010). 103 (984-995). $13 \mathrm{p}$.

Shah Alam, Md., S. Teshima, S. Koshio, M. Ishikawa, O. Uyan, L. H. H. Hernandez and F. R. Michael. 2005. Supplemental Effects of Coated Methionine and/or Lysine to Soy Protein Isolate Diet for Juvenile Kuruma Shrimp (Marsupenaeus japonicus). Aquaculture 248. (13-19). 6 p.

Tacon, A. G. J. 1987. The Nutrition and Feeding of Farmed Fish and Shrimp A Training Manual : 1. The Essential Nutrients. Food And Agriculture Organization. The United Nations. Brasilia, Brazil. 
Tidwell, J. H., S. Coyle., R. M. Durborow. S. Dasgupta., W. A. Wurts., F. Wynne., L. A. Bright and A. Van Arnum. 2002. Prawn Production Manual. Aquaculture Program. Kentucky State University. pp. 15, 18. 